TTR

Traduction, terminologie, rédaction

\title{
The Beginnings of Translation Studies
}

\section{Paul St-Pierre}

Volume 30, numéro 1-2, 1er semestre-2e semestre 2017

La traductologie en mouvement

Translations Studies: A Forward-Moving Discipline

URI : https://id.erudit.org/iderudit/1060020ar

DOI : https://doi.org/10.7202/1060020ar

Aller au sommaire du numéro

\section{Éditeur(s)}

Association canadienne de traductologie

\section{ISSN}

0835-8443 (imprimé)

1708-2188 (numérique)

\section{Découvrir la revue}

\section{Citer cet article}

St-Pierre, P. (2017). The Beginnings of Translation Studies. TTR, 30(1-2), 101-119. https://doi.org/10.7202/1060020ar

\section{Résumé de l'article}

C'est dans les années 1970 que l'objet d'étude dans les départements de littérature a commencé à changer, sous l'impulsion d'approches novatrices, certaines radicalement nouvelles et d'autres renouvelées - le structuralisme, la sémiotique, l'intertextualité, la psychanalyse, la pragmatique, la déconstruction, la théorie reader-response, l'herméneutique, l'analyse de discours, etc. Plusieurs (mais pas toutes) étaient d'origine partiellement ou entièrement française : on peut citer les noms de Lévi-Strauss, Barthes, Kristeva, Lacan, Derrida, Ricoeur et Foucault. Parallèlement à la modification de la définition de leur objet d'étude, les départements de littérature ont modifié comment ils se définissaient et le rôle qu'ils avaient à jouer. Cela ressort clairement de la façon dont les départements de littérature se sont renommés et ont introduit de nouveaux programmes. Ces changements ont eu lieu à différents moments dans des endroits différents, selon le degré d'accès aux publications - dont beaucoup étaient en français - et surtout en fonction des débats que ces publications ont provoqués. C'est dans ce contexte d'expansion et de redéfinition - présenté ici en fonction de mon histoire personnelle particulière - que l'intérêt pour la traduction, et plus tard pour la traductologie, s'est développé. Bien entendu, la traduction n'était pas un objet d'étude entièrement nouveau; les linguistes et les étudiants en littérature (en particulier en littérature comparée) avaient parfois reconnu son existence et même parfois son importance. Cependant, ce n'est qu'avec l'apparition de nouvelles approches aux textes, à la lecture, à l'interprétation et au contexte de la transmission du (des) sens et de l'expression - qu'une conception de l'importance de la traduction et de son intérêt théorique a pu se développer. Cela a conduit, dans les années 1980, au développement d'une discipline nouvelle : la traductologie.
Ce document est protégé par la loi sur le droit d'auteur. L’utilisation des services d'Érudit (y compris la reproduction) est assujettie à sa politique d'utilisation que vous pouvez consulter en ligne.

https://apropos.erudit.org/fr/usagers/politique-dutilisation/ 


\title{
The Beginnings of Translation Studies
}

\author{
Paul St-Pierre \\ Université de Montréal
}

\begin{abstract}
It was in the 1970s that the object of study in literature departments began to change, under the impetus of novel approaches, some radically new and others renewed forms of older ones-structuralism, semiotics, intertextuality, psychoanalysis, pragmatics, deconstruction, reader-response theory, hermeneutics, discourse analysis, etc. Many (but not all) of these were French in origin, at least in part: the names of Lévi-Strauss, Barthes, Kristeva, Lacan, Derrida, Ricoeur, Foucault can be cited. And along with the change in the definition of the object of study came a change in the way literature departments defined themselves and their role. This is clear from the way department of literatures renamed themselves and introduced new programs. These changes came about at different times in different places, dependent in good part on the amount of access that existed to the publications - many of which were in French-but especially to the debates they gave rise to. It was in this context of expansion and of redefinition - presented here in terms of my own particular history-that an interest in translation, and later in Translation Studies, developed. Of course, translation was not an entirely new object of study; linguists and students of literature (especially of comparative literature) had on occasion acknowledged its existence, and even at times, its importance. However, it was only with the advent of the new approaches to texts, to reading, to interpretation, and to the context of the transmission of meaning(s) and of expression, that a conception of the importance of translation, and of its interest from a theoretical point of view, was able to develop. This led, in the 1980s, to the construction of a new discipline-Translation Studies.
\end{abstract}

Keywords: translation studies, institution, (re)production, transformation

\section{Résumé}

C'est dans les années 1970 que l'objet d'étude dans les départements de littérature a commencé à changer, sous l'impulsion d'approches novatrices, certaines radicalement nouvelles et d'autres renouvelées - le structuralisme, la sémiotique, l'intertextualité, la psychanalyse, la pragmatique, la déconstruction, la théorie reader-response, l'herméneutique, l'analyse de discours, etc. Plusieurs (mais pas toutes) étaient d'origine partiellement ou entièrement française : on peut citer les noms de Lévi-Strauss, Barthes, Kristeva, Lacan, Derrida, Ricoeur 
et Foucault. Parallèlement à la modification de la définition de leur objet d'étude, les départements de littérature ont modifié comment ils se définissaient et le rôle qu'ils avaient à jouer. Cela ressort clairement de la façon dont les départements de littérature se sont renommés et ont introduit de nouveaux programmes. Ces changements ont eu lieu à différents moments dans des endroits différents, selon le degré d'accès aux publications - dont beaucoup étaient en français - et surtout en fonction des débats que ces publications ont provoqués. C'est dans ce contexte d'expansion et de redéfinition - présenté ici en fonction de mon histoire personnelle particulière - que l'intérêt pour la traduction, et plus tard pour la traductologie, s'est développé. Bien entendu, la traduction n'était pas un objet d'étude entièrement nouveau; les linguistes et les étudiants en littérature (en particulier en littérature comparée) avaient parfois reconnu son existence et même parfois son importance. Cependant, ce n'est qu'avec l'apparition de nouvelles approches aux textes, à la lecture, à l'interprétation et au contexte de la transmission du (des) sens et de l'expression - qu'une conception de l'importance de la traduction et de son intérêt théorique a pu se développer. Cela a conduit, dans les années 1980, au développement d'une discipline nouvelle : la traductologie.

Mots-clés : traductologie, institution, (re)production, transformation

What follows is simply one account of the beginnings of Translation Studies, based on my personal trajectory as a Ph.D. student working on French literature in the 1970s, on a topic related to translation. Rather than an objective history of the development of the field as a whole, this is meant to be an experiential and autobiographical chronicle that, it is to be hoped, will have an interest beyond what is a purely personal narrative.

In 1969 I enrolled in the Department of French at the University of Toronto to do a Ph.D. The size of the department at the timesome 130 professors teaching at the graduate level—was impressive, and a sign of institutional and disciplinary robustness. Studies in the department were based on-and the following words are in single quotation marks, since what they actually meant became open to question-'coverage' of 'the field,' with coursework and 'comprehensive' Ph.D. examinations. In addition to French, students were expected to have a working knowledge of Latin, German, and of another Romance language. My thesis was to be on the novels of Samuel Beckett and the question of self-translation-a somewhat untraditional decision in the choice of the author (does his work 
belong to French literature, or to English?) as well as of the topic (was it acceptable to work on translation in a literature department?). Nevertheless, the path forward, in institutional terms, seemed clearly set out at the time. But change was brewing, and it was this change that would subsequently affect literature departments throughout the world, unequally and with distinct chronologies for departments in different locations.

"Things fall apart; the centre cannot hold;

Mere anarchy is loosed upon the world"

These lines from William Butler Yeats' "The Second Coming” are perhaps a fitting introduction to what was taking place in Europe and North America-but more specifically in France and in the United States - in the late 1960s, with the opposition to, and the at least temporary breakdown of, institutional structures: the riots and contestation of society during May 1968 in France, and opposition to the war against Vietnam on American campuses and in American streets. These events were not the "causes" as such of what had already begun to take place within academic disciplines, but were the political and social manifestations of a "centre" that could no longer "hold." And so it was, that in the late 1960s and early 1970s, something later to be labelled as "French theory" developed: structuralism, semiology (as the approaches to semiotics that developed in France were called), psychoanalysis, deconstruction, discourse analysis, intertextuality, etc. Of course, the proponents and origins of these theoretical approaches were not only French, but many were, at least through their institutional affiliations if not by their birthplaces: Roland Barthes, Jacques Derrida, Michel Foucault, Algirdas Greimas, Julia Kristeva, Jacques Lacan, Claude LéviStrauss, to cite only a few. These approaches did not all define their theoretical objects in the same way, and tensions famously existed between them-between structuralism and Marxism, for example, or between the semiology of Barthes and that of Greimas-yet the copresence of these theories, largely in the concentrated geographical space of Paris, was to have a profound effect on the way literatures were studied throughout the world. As it spread, was translated, and in the process transformed, "French theory" took on new forms and meanings in new contexts (consider Derridean theories in the United States, for example)—some even unrecognizable to the authors whose names were associated with them-and they 
gradually and progressively set to undermining existing structures and approaches. The explanation of a work's meaning through a presentation of the biography of its author was no longer satisfactory, if ever it had been, as "works" became "texts," and texts produced meanings in their interaction with other texts and with readers; reading, interpretation, and writing about texts all became acts of producing meaning, and not simply of reproducing meaning. This change was at the heart of the work of Kristeva, Barthes, and Derrida-to name only these theoreticians.

Thus, the object of study in literature departments began to change- the text rather than the work, the text rather than the author - a change that met with both acceptance and resistance, depending on the institution, the department of literature, the vested interests within the departments and institutions, and also depending on the access to these theoretical approaches, most often through translations. With this change of object came an expansion of the way in which departments of literature defined themselves and their function, opening up-despite what was often a great deal of resistance - to more interdisciplinary fields of research: area studies, but also critical studies and theory, cultural studies, gender studies, etc. And also to translation, and subsequently-since in the early 1970s this field did not as yet exist—-to Translation Studies.

The finality of departments of literature was also put into question, in particular as the job market for graduates of literature programs became more and more limited. Departments shrank in size; the number of applicants dwindled. Gradually_and again not without a good deal of resistance-new objectives, other than simply producing/reproducing teachers of literature, were entertained. Students could be trained for other sorts of jobs, and, indeed, the very survival of the literature departments demanded that they were. Various skills could be developed-analytical skills, communicational skills, translational skills-to mention only these. The decentring of literary studies had begun, through a redefinition of the object and the interrogation of the distinction between the literary and the non-literary, resulting in a redefinition of the reasons for studying literature.

As mentioned earlier, when I enrolled in the doctoral program at the University of Toronto, the Department of French was very traditional in its setup, defining "literature" in a narrow way and expecting of its students a comprehensive mastery of vast segments 
of the field. The only places on the curriculum where the effects of time and the specific geographical location of the department could be felt were the inclusion in the syllabus of a course on "stylistics"defined in a very traditional manner, however-and, almost as an afterthought, of a course on the French literature of Québec. Despite this, the signs of change could not be denied, even if located outside the walls of the department: in a newly-founded and alreadythriving semiotics institute, for example, run by a professor from the French Department with a passion for circuses (with, among its visiting Faculty: Michel Foucault, Michael Riffaterre, and Umberto Eco); in the visiting professors brought in, most notably, by the Department of Comparative Literature (Fredric Jameson, Wolfgang Iser, Timothy Reiss, to name only three); in the international colloquia organized by the French Department, where theories were passionately debated and even fought over; and, finally, in the reading groups formed by students and junior faculty members, to read texts other than those traditionally found on an unchanging curriculum. I myself participated in two such groups during my years in Toronto doing my doctorate, on the works of Marx and of Freud.

Another way of going beyond the walls of the department was to expatriate oneself. Thus, while working on my thesis I spent two years studying in Paris (after two earlier years at the Université de Grenoble, and interspersed with one at the Université de Nice), familiarizing myself with the work of Barthes and Kristeva, both of whom taught courses and seminars that I attended. They also participated in the evaluation of my progress as a scholar, for a Diplôme d'études approfondies in semiology at the Université de Paris VII, in the case of Barthes, and for my Ph.D., in the case of Kristeva. Through contact with their work and their teaching, the subject of my thesis evolved, as did my conception of what it meant to translate. The distinction between "original," "creative" writing and "noncreative" translation broke down. Influenced by notions such as "text" (Barthes), "discourse" (Foucault), and "productivity" (Kristeva), I came to see Beckett's self-translation as a continuation of the writing process, across languages, rather than as something divorced from and different from "creation" - and of course the notion of the absolute creativity of literary texts was itself in the process of being put into question through the theoretical work centring on intertextuality, most notably by Michael Riffaterre at Columbia University and by Julia Kristeva. My approach to Beckett's works 
was "translation studies" before the field had been constituted as such: the application of new theories and approaches to the object "translation," conceived of as a product but, and more importantly, also as a process. Translation was becoming for me something that needed to be studied as a social, cultural, and historical artefact, and as a process necessarily involving the transformation of a source text. This is what Translation Studies would do, with its founding in the 1980s. Fundamentally interdisciplinary in nature, despite most often being located within national departments of literature or of language, the development of Translation Studies was also a part of the decentring of literary studies that had begun in the 1960s, a part of what is still an on-going process of re-locating institutional structures.

Both the tension between traditional and new approaches, and the evolution between strictly literary and more avowedly "textual" approaches, is explicitly apparent in the thesis- "Langues et langage dans cinq textes de Beckett"-I was preparing and eventually defended during these years in which structures and strictures were increasingly contested. Of the theoretical works cited in the thesis, the vast majority were published in the ten years preceding my defence in January 1977. In other words, almost all appeared during the very period in which my research was being conducted and the thesis was being written. Indeed, the sole works published before 1967 were a few texts by Roland Barthes (Sur Racine, Essais critiques, "La Rature," Critique et vérité, "L'Effet du réel"), Thomas Kuhn's The Structure of Scientific Revolutions, Sigmund Freud's "Delusion and Dream in Jensen's Gradiva," Émile Benveniste's Problèmes de linguistique générale, Ferdinand de Saussure's Cours de linguistique générale, and Roman Jakobson's Essais de linguistique générale-all classic, important, and in no sense simply "traditional" works. My thesis was turned resolutely towards the present, in its references, and towards the future, in its attempt to contest certain accepted approaches and to propose others.

Nowhere was this more visible that in the two chapters devoted to translation theory as such. And, in fact, the first half of the 1970s would turn out to be an important period for what would develop into Translation Studies, with the appearance of issues of journals such as Langages in 1972, and Change in 1973 and again in 1974, as 
well as works by Henri Meschonnic (Pour la poétique II in 1973) and by George Steiner (After Babel in 1975, in addition to the 96-page response to this work by Paolo Valesio that appeared in Semiotica in 1976). These writings were often by critics who, in addition to being practitioners of translation, were also theoreticians at the forefront of critical thought, and their proposals - in what they brought that was "innovative"-reflected this. The works on translation contained in the bibliography of my thesis-there were some 240 entriesreflect the importance of what was being written at the time. There were 13 entries for works that appeared prior to 1950, 27 published during the 1950s, 59 for publications during the 1960s, and 141 of the entries were for works published between 1970 and 1976. The emphasis placed on publications contemporaneous to the writing of my thesis reflected, of course, my own biases, but it also constituted testimony to the burgeoning field of work on translation.

In a chapter entitled "Écriture et traduction," a critique of what I characterized as the "traditional" discourse on translation was undertaken. The basis for this critique was stated as follows:

Il semble donc que le discours traditionnel et moral sur la traduction occulte la pratique, à la fois au niveau de l'écrit et au niveau de l'acte de traduire. (p.13)

In this way my thesis positioned itself against an approach characterized as traditional and "moral," that is, essentially normative in nature, under the influence of critics and theoreticians writing mostly about literary texts and how meaning was produced in them through the practices of "reading" and "writing." It is in this positioning that the space that was opening up for Translation Studies to develop can be glimpsed. This critique of traditional approaches was carried out under four headings:

1. Language: transparent or opaque;

2. Text: product or production;

3. Act of translation: reproduction or practice; and

4: Sociality and Historicity: denied or admitted.

These binary oppositions were clearly somewhat reductive and overly simplistic, and this was recognized as such in the thesis itself, since they would be modulated in the chapter that followed: "Les trois niveaux de la traduction." They did serve, however, to indicate an approach to translation and to translations that was different 
from what had previously been adopted. This new approach did not limit the purpose of translation to the reproduction of a content, of an original text, of a referent, or of an effect. The critique took aim at the notion of "equivalence," something that Translation Studies, once it had been constituted as a field, in the sense of Pierre Bourdieu, would revisit and develop at much greater length. It was in the last section, on the social and historical nature both of the original text and of the translation, that the thesis broke most strongly with past discourses on translation, through its emphasis on the importance for any consideration of translation and of translations of the roles of context, culture, linguistic structures, and history in the construction of meaning, of course, and of the texts themselves.

If the first chapter of my thesis constituted an attempt to provide a way of thinking about translation and translations that ran counter to "traditional" discourse, the second, on the three levels of translation, was founded on the desire to subsume both traditional discourse and its counterpart under a more general theory that could account for the existence of them both. After attempting to show the necessity of a counter discourse on translation, it now became important to produce a synthesis of the two. My theorisation was based on the work of Luis J. Prieto, whom I had heard speak in 1974 in Milan at the first world congress of the International Association for Semiotic Studies. In this talk, and in Pertinence et pratique, published by Les Éditions de Minuit the following year, Prieto distinguished between a sound, a phoneme, and phonology in order to discuss different types of objectivity. Whereas a sound forms part of material reality, and as such cannot be fully known, defined, or characterized, a phoneme is a selection of certain, limited qualities of the sound, on the basis of specific criteria. These criteria do not find their grounding in the sound itself. In the case of phonemes, they are related to the production of meaning. Thus, while certain qualities, and only certain qualities, of a sound are "pertinent" for a given language (for English, for example, the distinction between voiced and unvoiced is meaningful in the case of $/ \mathrm{d} /$ and $/ \mathrm{t} /$ ), they may not be for a different language (such as the Indian language Odia). Phonemes, because they are constituted by a selection of qualities, can be described in full-and their description is the task of phonology. At the level of the sound there can be no objectivity, given the limitless nature of a constituent of material reality. At the level of the phoneme, objectivity consists in making evident the 
criteria - the relation to the production of meaning, in the case of phonemes-which have served in the selection of a limited number of qualities of the sound. Prieto characterizes the objectivity possible at this level as that of the natural sciences: the making evident of the criteria used in the selection of qualities forming phonemes, since the relation of the phoneme to the sound is based on the pertinence of certain elements. Finally, the objects of phonology are phonemes, and phonology is able to describe these objects in their totality and "objectively." For Prieto this is the level of the objectivity of the human sciences, whose objects are "constructed" rather than "naturally" occurring. Thus, paradoxically, for Prieto, whereas the objectivity of the natural sciences relies on making known the basis on which certain elements of the natural world are being selected, a basis which is independent of these elements themselves, the objectivity of the social sciences is based on making clear the constructed nature of its object, with the possibility of total objectivity ("objectivity" in the sense of the knowledge of the object being determined by the object itself).

These distinctions made by Prieto between fundamentally different sorts of objects and types of corresponding objectivity are definitely challenging, but it nevertheless seemed to me at the time of writing my thesis, and still today, more than forty years later, that they can be useful for a discussion of translation and translations.

Is the practice of translation, is $a$ translation, to be situated at the level of a sound, of a phoneme, or of phonology? My answer, and this speaks to the complexity of both translation and translations, is that they are situated at the level of all three, simultaneously. As a written text or a cultural practice, translation and translations simply exist in the world. As such, our knowledge of them can only by partial and fragmentary; we can only provide an incomplete and temporary description, or account, of them. But a translation is also a "partial perception" of an object in the world (the original text): a translation has a relation to another text, and this perception is grounded in the selection, based on criteria which derive from the context, of elements (the meaning of the original text, its referent-if this term can be used with reference to a literary text, its effect-but other criteria as well). Because the perception that is a translation is based on a selection, it is necessarily partial-incomplete and, in a sense, biased-in nature. This observation is crucial to the understanding that a translation is always incomplete, always "unfaithful," always replaceable - at another time or in another place other selections, 
based on different criteria, will be made. Finally, a translation is also situated at the level of phonology, and as such it can objectively re-present the viewpoint contained within the text it translates, a text that is itself a "partial perception," that is, a social and historical perception of the world. This perception, because it is necessarily made up of a limited number of elements, can be objectively reproduced by a translation.

Translation and translations operate simultaneously on three distinct levels: on the level of a practice (textual, cultural, social, historical, etc.), on the level of partial perception, and on the level of objective reproduction. On the level of practice, no notion of objectivity is operable, since there is no immediate relation to, or perception of, another object. On the level of "partial perception," objectivity derives from the description and definition of the terms under which the selection of elements is being made. On the level of objective reproduction, the translation has as its goal to "reproduce" the perceptions present within the original text, and insofar as it does succeed in reproducing them, the translation is "objective."

This is, of course, a very formalistic reading of the way in which translation and translations can be considered to operate. But it can help explain both why it is possible to evaluate a translation in terms of its success in re-presenting a text, and also to accept that no matter how great that success is, new, equally successful and yet very different translations also become possible. This approach makes it possible to account for how a translation can at one and the same time be "faithful" and "unfaithful."

The interplay between these three textual levels in translation can be illustrated through two examples. The first is "Last Night," an Urdu quatrain by Faiz Ahmed Faiz (1911-1984), which has received multiple translations in English, some thirty-four of which are collected in Faiz Abmed Faiz. Last Night. The Quatrain in Multiple Translations, edited by K.K. Mohapatra, Leelawati Mohapatra, and Paul St-Pierre (2011). In a short preface to this volume, I note:

Somehow, in each instantiation, at once something shared and something distinct is overheard; not the betrayal of translation, rather its constancy and indirection. (p. 12) 
It is this combination of something both shared and distinct that makes multiple translations possible and necessary. It is because the original work is open to the different perceptions of the various translators, and the fact that these perceptions are given form through another language, and, more importantly, through another text, that different translations become possible, while remaining, despite all that distinguishes them, translations of the same text. This multiplicity and diversity is a constant of translation, the direct result of the possibilities contained within and realized through interpretation (perception) and through the process of writing. All translations emphasize certain aspects of the texts they re-present, all the while occulting others.

To illustrate the constancy and indirection that translation involves and that is made visible in these different translations, let me simply cite three versions of the first line of the quatrain by Faiz Ahmed Faiz. The first is by Frances Pritchett (p. 31):

Last night, your lost memory came into my heart.

The second and the third are both by David Lunn:

a) They came-those lost and faded memories of you — last night (p. 39)

b) Both unannounced and uninvited, brash and without shame,/ those memories I'd thought forgotten — suddenly they came;/ as faded as they were, yet still they had the power to bring/ a wrenching recollection of your face, your voice, your name. (p. 41)

Despite their clear differences, attributable to the difference in translators as well as to the difference in the projects the translators adopt, one can recognize that all three are indeed translations of the same text. In these different translations there is both constancyin the recognition of a certain similarity underlying these different texts-and indirection-in the different ways in which this similarity is given expression in English. The differences between the translations point both to their status as texts in English and to their activation in different ways of elements of the original text; the similarities between the translations-which make it possible to consider all three as "translations" of the first line of the quatrain by Faiz Ahmed Faiz - point to the fact that they all have a common text as their source, and that, in this case, the re-presentation effectuated through translation is also a reproduction. 
The second example is taken from prose, lest poetry be considered an exceptional case. Under consideration are the first few sentences of the Odia novel Chba mana atha guntha, published in 1902 and considered not only the first social realist novel in any Indian language but also the greatest novel in Odia, the language of Odisha, on the east coast of India, and one of the twenty-two official languages of that country. These first few sentences of the novel are provided here (see Annex) in seven different translations: the first literal, to give a sense of the organization of the original text and of the structures of the original language, followed by six others, both published and unpublished.

Each of these different translations is characterized by a "project" that defines it and that accounts for the various choices made by the translators. In almost all the translations words foreign to, or uncommon in, English are used, defined or glossed within the text itself [Translation \#2: "is a village landlord (zamindar)"; Translation \#3: "the professional sway of the Samant (we mean Mangaraj himself by this title of gentility)"; Translation \#6: "a zamindar-a rural landlord"] or in a footnote ("mofussil" in Translation \#4) or a glossary ("krosas" in Translation \#5 and "kos" in Translation \#6). The words selected for such treatment vary between the translations, which would seem to indicate that this is dependent more on the translators' view of their particular project (and of their potential readers) than on any determining effect of the original text as such.

A brief examination of the treatment of a particular termekadashi-will illustrate the variety of ways in which the different translations handle a term specific to the cultural context of the original work. The term ekadashi (also spelt ekadasi in English) refers to the eleventh day of each of the two lunar phases (waxing and waning) occurring in a Hindu calendar month. The day has spiritual significance for observant Hindus, who on it undertake a fast. In Translation \#2, the word is used (and capitalized) by the translator, and defined in an additional sentence, separated by parentheses from the body of the novel: "all the Ekadasi days. (11 ${ }^{\text {th }}$ day, of both phases of the moon)." The translator intervenes here to provide additional information for the reader, which fits with the purpose for which the translation was being produced: i.e., to acquaint an American professor of anthropology with Odia customs of which he may not otherwise have been aware. Translation \#3, goes beyond 
simply providing the definition of the terms, instead integrating this information in the "Englished" flow of the text, the text that the author would have written-or so claims the translator, echoing the words of John Dryden on translation - "if he had come to write in English today." Thus the translation sums up in two complete sentences both what "Ekadasi days" are and what they signify:

There are two Ekadasi days in the course of each month of the Hindu calendar, one coming up during the dark fortnight and the other during the bright fortnight. It follows, therefore, that there are twenty-four Ekadsai (sic) days in all in the year; and it is around them that a good deal of Hindu piety collects itself generally.

In Translation \#4, published in the 1960s by the Government of India with a view to promoting within India a "unified view of Indian life," the term is not explained but rather, through italicization, drawn attention to as specific to a culture other than that of the translation, specific, that is, to Indian culture: "all the 24 Ekadashi fasts over the year." A word of explanation- "fasts"-is added, in translations \#5 and \#7, as a way of reinforcing what is specifically connected in the use of the term to Hindu religion and practices. In Translation \#5, the number of such days in the year rather than specific reference to the term itself is given, as is the activity to be observed (fasting): "all the 24 fasting days around the year." Finally, Translation \#6 uses the term without defining or glossing it ("twenty-four ekadasis in a year"), while Translation \#7 glosses the term without using it ("twenty-four lunar fast days in a year").

These seven translations of the introductory lines of Chba mana ath a guntha show great variability in the rendering of the original text, while at the same time being translations of the same original text, and clearly so. The translations are defined by the different "projects" of the translators and publishers, these "projects" corresponding to what I have been calling "perceptions." The similarity between the different translations-even in the case of the expanded version by C.V.N. Das (Translation \#3) - points to the fact they re-produce elements, and more specifically perceptions, contained within the original text. But each of these translations is different from all the others, since each is also a text written in English. 
What has been presented here may be a singular history, specific to a time and place, but it is also a history of the beginnings of the discipline of Translation Studies, which would develop into a full-fledged field in the 1980s, with its own journals, conferences, university programs, professional associations, and theories. As it began to take on its own identity, it "distinguished" itself from other, older fields - from literary studies, for example, or from linguistics. In doing so, Translation Studies faced—and still faces—both attacks and incomprehension. ${ }^{1}$ On the part of funding agencies, most notably, but not solely, and in the failure to recognize the intricate relation between theory and practice in the field. In the more than forty years that have passed since some of the events recounted in this article, great progress has been made and a field of studies defined. Yet, the incomprehension - wilful in certain cases, when and where there are parochial interests to be defended-continues still. An understanding of the beginning of Translation Studies should serve both to mark all that has been achieved and to underline the need for concrete measures to be taken in the future to overcome the persisting lack of full recognition accorded the field.

\section{References}

Behera, Krushnacharan and Debendra Dash, eds. (2000). Phakirmohan Granthabali. Volume I. Cuttack, Grantha Mandir.

Change, 14 (1973).

Change, 19 (1974).

Faiz, Faiz Ahmed (2011). Last Night. The Quatrain in Multiple Translations. Bhubaneswar, Four Corners Press.

Langages, 28 (1972).

Meschonnic, Henri (1973). Pour la poétique II. Paris, Gallimard.

Prieto, Luis J. (1975). Pertinence et pratique. Le sens commun. Paris, Les Éditions de Minuit.

Senapati, Phakirmohan (1967). The Stubble Under the Cloven Hoof. Trans. C.V. Narasimha Das. Cuttack, Sahitya Samsad.

Senapati, Phakirmohan (1967). Six Acres and a Half. Trans. B.M. Senapati and A.M. Senapati. New Delhi, Publications Division, Ministry of Information and Broadcasting, Government of India.

Senapati, Phakirmohan (1969). A Plot of Land. Trans. Nuri Mishra. Cuttack, Cuttack Students' Store.

1. For further information on the constitution of new fields of study, and the threat to established fields they can pose, in particular in relation to the constitution of the field of Translation Studies, see Simeoni (2007). 
Senapati, Phakirmohan (1980s; published privately in 2019). Chha Mana Atha Guntha (Six Acres and One Third). Trans. Sanjukta Mahapatra.

Senapati, Phakirmohan (2005). Six Acres and a Third. Trans. Rabi Shankar Mishra, Satya Prakash Mohanty, Jatindra Kumar Nayak, and Paul StPierre. Berkeley, University of California Press. Republished by Penguin Books, New Delhi, in 2006.

Senapati, Phakirmohan (2018). Six and a Third Acres. Trans. K.K. Mohapatra, Leelawati Mohapatra, and Paul St-Pierre. Unpublished.

Simeoni, Daniel (2007). "Between Sociology and History. Method and Context in Practice." In M. Wolf and A. Fukari, eds. Constructing a Sociology of Translation. Amsterdam/Philadelphia, John Benjamins, pp. 187-204.

Steiner, George (1975). After Babel. Aspects of Language and Translation. London, Oxford University Press.

Valesio, Paolo (1976). "The Virtues of Traducement: Sketch of a Theory of Translation.” Semiotica, 18, pp. 1-96.

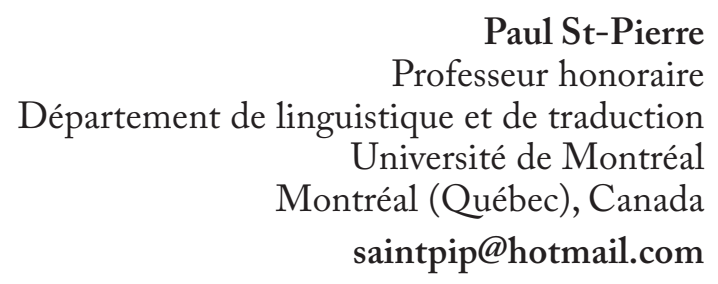




\section{Annex}

Given below are the first few lines of Chba mana atha guntha, by Phakirmohan Senapati (1843-1918), in different translations.

1. A literal transcription from Odia into English (in brackets) by K.K. Mohapatra:

Ramachandra Mangaraj (Ramachandra Mangaraj) jane (one) mofussilra (in/of mofussil) jamidar (zamindar; big landowner). Nagada (ready) tanka (cash/money) karabaratharu (more business) dhanarar (in paddy/rice grains) mahajani (lending) besi (higher/ greater). Sunajae (heard/overheard/heard through the grapevine) ade dirghe (breadth length) chari kosh (four kos) madhyare (within/ in the radius of) aau kahari (anyone else's) karabara (business) chalenahin (does not run). Lokati (The/this man) bada (very) dharmika (spiritual/religious). Basha (year/annual) madhyare (within/in) chabishta (twenty-four) ekadashi (ekadashi/11 ${ }^{\text {th }}$ day of the lunar calendar), chalishta (forty) thile (there were) gotae (one) je (that) chahdapadanta (omitted/left/overlooked), ekatha (this thing/ this word/this matter) ambhemane (we; royal plual) kahibabku ((to say/to utter/to claim) akhyama (unable).

2. A translation from the 1980s privately published in 2019 by Sanjukta Mahapatra for an anthropology professor from the University of Chicago, to acquaint him with this masterpiece of Odia literature:

Ramachandra Mangaraj is a village landlord (zamindar) as well as a rich merchant, who deals mainly in paddy. It has been said that no merchant operates within a radius of eight miles. The man is rather holy, and observes fast and worship on all the Ekadasi days. (11 ${ }^{\text {th }}$ day, of both phases of the moon).

3. "An imaginative recast" of the novel by C.V. Narsimha Das, published as The Stubble Under the Cloven Hoof. The translator has written an introductory text "The Author to the Reader," in which he states his purpose as follows:

Fakir Mohan himself, I fancy, would have written something vitally like this book if he had come to write in English today. He would have poured his genius, which chiefly means his hilarity, into such an English mould as this .... This fancy operated at every step by leading 
me to flood-light Fakir Mohan's genius through a temperament rather than through a formal fidelity of sentences.

The following first lines of the novel are preceded by an excerpt from Act 1, Scene 3 of The Merchant of Venice, not found in the original text:

At once an estate-holder and a money-lender, Ramachandra Mangaraj has chosen to ply his business in the money-lending line by advancing the bulk of his loans in the shape of grain rather than money. There is a consensus of opinion among the competent judges of Govindapur, who do not draw the long bow, that over eight long miles around that village the professional sway of the Samant (we mean Mangaraj himself by this title of gentility) is absolute. But the sheet-anchor of his life is his profound piety which, like his professional sway, has evoked at once the envy and despair of all men. Indeed his moral loftiness springs from his devout temper and, of course, also from his wisdom which is deeply rooted in the fear of the Lord. There are two Ekadasi days in the course of each month of the Hindu calendar, one coming up during the dark fortnight and the other during the bright fortnight. It follows, therefore, that there are twenty-four Ekadsai (sic) days in all in the year; and it is around them that a good deal of Hindu piety collects itself generally. But if there had been forty Ekadasi days every year instead, it would have been impossible for us to say that one out of them slipped away without finding the Samant in the grip of his devotional ardours.

\section{A translation by B.M. Senapati and A.M. Senapati: Six Acres and} a Half. The translators present their work in their "Translators' Note" in part as follows:

We have made the English translation as true to the original as practicable. We hope this will facilitate, among the reading public of this vast sub-continent of India, a closer understanding of life in Orissa in the last century; in so doing it may promote that unified view of Indian life which is unmistakable in spite of the rich diversity of our country.

The translation reads as follows:

Ramchandra Mangaraj was a mofussil* Zamindar. He carried on an extensive business in lending paddy and money. Rumour goes that within a radius of eight miles no one else had so much moneylending business. Mangaraj was a pious man who observed all the 24 Ekadashi fasts over the year. Had there been 40 a year, he would not have missed a single one either. 
And the following footnote for "mofussil" appears at the bottom of the page:

That is to say, living in the countryside, unlike many big ("absentee") landlords who lived in the metropolis, Calcutta, or at least in big towns like Cuttack.

5. A translation by Nuri Mishra: A Plot of Land. The translator remarks in the unpaginated "Preface": "Without changing the structure and style of the original story, the translator has tried to rewrite the same so as to enable it to be used as an easy reader for whom English is a second language."

Rama Chandra Mangaraj was a village Zamindar. He was also a creditor who used to lend money and paddy as well. He had no equal in wealth within krosas of his village. He was a pious man and observed all the 24 fasting days around the year. Had there been 40 such days, he would not have missed any one.

The word "krosa" is defined in the "Glossary" as "Approximately 3 kilometres."

6. A translation by Rabi Shankar Mishra, Satya Prakash Mohanty, Jatindra Kumar Nayak, Paul St-Pierre: Six Acres and a Third.

Ramachandra Mangaraj was a zamindar-a rural landlord-and a prominent moneylender as well, though his transactions in grain far exceeded those in cash. For an area of four kos around, no one else's business had much influence. He was a very pious man indeed: there are twenty-four ekadasis in a year; even if there had been forty such holy days he would have observed every single one. This is indisputable.

A definition of "kos" appears in a "Glossary" as "A measure of distance, approximately two kilometers."

7. A new and as yet unpublished translation by K.K. Mohapatra, Leelawati Mohapatra, Paul St-Pierre: Six and a Third Acres. One of the translators-K.K. Mohapatra-sets out the reason for this new translation in the following terms:

There are at least two important reasons for this undertaking. The first is of an objective nature. All the four previous translations were based on flawed versions of the original text, which over the years had 
suffered various changes. The latest translation has the advantage of being based on the established scholarly edition of Chha Mana Atha Guntha contained in Fakir Mohan Granthabali (Vol. 1), edited by Krushnacharan Behera and Debendra Dash [...] The second reason is perhaps more subjective, but equally important in terms of how Fakir Mohan's great novel will be received. The previous versions-perhaps with the exception of that by Rao, but there are other problems with that translation, given its expansion of the work-all failed to fully capture the author's tone.

The translation reads as follows:

Ramchandra Mangaraj was a country zamindar, with vast tracts of land. He was also a moneylender, giving out loans more in grain than in cash, and was rumoured to have eclipsed all others within eight miles of Govindpur.

He was an exceptionally pious man, an observer of fasts and vigils. Though there may be twenty-four lunar fast days in a year, had there been as many as forty we'd be hard pressed to say he'd have skipped even one. 